\title{
In vitro Multiplication of the Pitcher Plant Sarracenia Purpurea
}

\author{
Ileana MICLEA ${ }^{1 *}$, Rita BERNAT ${ }^{1}$ \\ ${ }^{1}$ Department of Animal Reproduction, University of Agricultural Sciences and Veterinary Medicine, 3-5, \\ Mănăştur Street, 400372, Cluj-Napoca, Romania. \\ *Corresponding author, e-mail: ileana.miclea@usamvcluj.ro
}

Bulletin UASVM Animal Science and Biotechnologies 75(2)/ 2018

Print ISSN 1843-5262; Electronic ISSN 1843-536X

DOI:10.15835/buasvmcn-asb: 2018.0018

\begin{abstract}
The aim of the current research was to find the best plant growth regulators for the multiplication of Sarracenia purpurea. Murashige and Skoog medium (MS) was prepared with macronutrients and micronutrients at $1 / 3$ strength, full strength vitamins, supplemented with $30 \mathrm{~g} / \mathrm{l}$ sucrose and $5 \mathrm{~g} / \mathrm{l}$ phytagel and autoclaved. After cooling $0.5 \mathrm{mg} \backslash \mathrm{l} \alpha$-naphthaleneacetic acid (NAA), $5 \mathrm{mg} \backslash \mathrm{l}$ 6-benzyladenine (BA) or $0.5 \mathrm{mg} \backslash \mathrm{l} \mathrm{NAA}+3 \mathrm{mg} \backslash \mathrm{l}$ BA were added. Young $S$. purpurea plants were selected and transferred to media with or without plant growth regulators and cultured for 12 weeks. At the end of this time frame number of roots, root length $(\mathrm{cm})$ and number of shoots were evaluated and differences were analysed by the analysis of variance and interpreted using the Tuckey test. The largest number of roots grew in medium supplemented with $0.5 \mathrm{mg} \backslash 1 \mathrm{NAA}$ but the the absence of plant growth regulators increased their length. The best conditions for shoot multiplication were provided by supplementing 1/3MS with $5 \mathrm{mg} \backslash \mathrm{l}$ BA.
\end{abstract}

Keywords: in vitro propagation, Sarraccenia purpurea

\section{INTRODUCTION}

Sarracenia purpurea L. (Sarraceniaceae), is a perennial carnivorous plant widely distributed in North America (Harris et al., 2012). It grows in bog environments where the acidic soil is poor in nutrients, particularly nitrogen so it adapts by trapping insects in highly modified and fused leaves (pitchers) and consuming them (Rogers et al., 2010). S. purpurea has come to the attention of hobby horticulturists (Northcutt and Davies, 2012) and although many Sarracenia species are endangered, mainly by loss of habitat (Uhnak, 2003), poachers still harvest wild plants illegally to sell to collectors (Stiefel, 2000). This species is well known for its uses in traditional medicine (Guerrero-Analco et al., 2014), it can inhibit poxvirus replication at the level of early viral transcription (Arndt et al., 2012), afford protection against diabetic neuropathy (Eid and Haddad, 2014) but also cause apoptosis in renal cells ( $\mathrm{Li}$ et al., 2018).In this context micropropagation becomes an alternative source to produce large numbers of plants to be sold or used for the extraction of secondary metabolites. The aim of our research was to find the most fitting plant growth regulators for the multiplication of $S$. purpurea.

\section{MATERIALS AND METHODS}

Reagents were acquired from Duchefa Biochemie, The Netherlands. Murashige and Skoog medium (1962, MS) was prepared with macronutrients and micronutrients at $1 / 3$ strength (1/3MS), full strength vitamins, supplemented with $30 \mathrm{~g} / \mathrm{l}$ sucrose, solidified with $5 \mathrm{~g} / \mathrm{l}$ phytagel and $\mathrm{pH}$ was adjusted to 5.4- 
Tab. 1. Effects of growth regulators on plant multiplication in S. purpurea

\begin{tabular}{cccc}
\hline Treatment & No. roots/explant & Root length $(\mathrm{cm})$ & No. shoots/explant \\
\hline Control & $4.56 \pm 0.95 \mathrm{a}$ & $4.12 \pm 0.82 \mathrm{a}$ & $1.14 \pm 0.19 \mathrm{a}$ \\
\hline $0.5 \mathrm{mg} \backslash \mathrm{l} \mathrm{NAA}$ & $6.79 \pm 0.45 \mathrm{c}$ & $2.60 \pm 0.38 \mathrm{a}$ & $1.87 \pm 0.19 \mathrm{a}$ \\
\hline $5 \mathrm{mg} \backslash \mathrm{l} \mathrm{BA}$ & $0.48 \pm 0.17 \mathrm{bd}$ & $0.45 \pm 0.13 \mathrm{bc}$ & $3.75 \pm 0.36 \mathrm{~b}$ \\
\hline $\begin{array}{c}0.5 \mathrm{mg} \backslash \mathrm{NAA}+ \\
3 \mathrm{mg} \backslash \mathrm{l} \mathrm{BA}\end{array}$ & $0.30 \pm 0.20 \mathrm{~d}$ & $0.18 \pm 0.13 \mathrm{c}$ & $2.12 \pm 0.43 \mathrm{a}$ \\
\hline
\end{tabular}

Note: Values expressed are mean \pm standard error of the mean (SEM). Different letters between means within the same column denote significant differences $(\mathrm{p}<0.05)$.
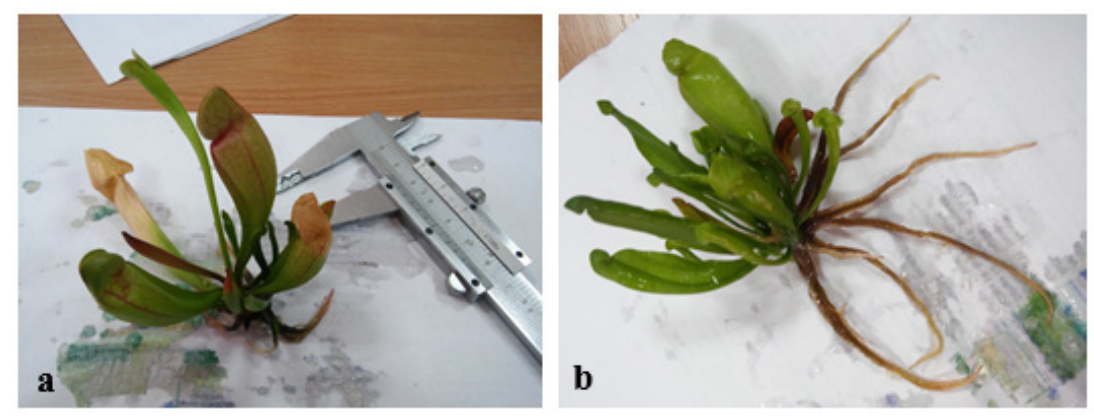

Fig. 1. S. purpurea shoots with poorly developed roots (a) and with well developed roots

(b) 12 weeks after being placed in culture medium.

5.5 before autoclaving at $121^{\circ} \mathrm{C}$ for $20 \mathrm{~min}$. After cooling $0.5 \mathrm{mg} \backslash \mathrm{l} \alpha$-naphthaleneacetic acid (NAA), $5 \mathrm{mg} \backslash \mathrm{l}$ 6-benzyladenine (BA) or $0.5 \mathrm{mg} \backslash \mathrm{l} \mathrm{NAA}+$ $3 \mathrm{mg} \backslash \mathrm{l}$ BA were added to the medium and it was dispersed in culture vessels. Young $S$. purpurea plants from established in vitro cultures were selected and transferred to media with or without plant growth regulators and kept for 12 weeks in the growth chamber at $20-25^{\circ} \mathrm{C}$ under a $18 / 6$ $\mathrm{h}$ light/dark regime provided by cool white fluorescent lamps with a light intensity of 40 $\mu \mathrm{mol} / \mathrm{m}^{2} / \mathrm{s}$. At the end of this time the number of roots, root length $(\mathrm{cm})$ and number of shoots were assessed and differences were analysed by the analysis of variance and interpreted using the Tuckey test with $\mathrm{p}<0.05$ being considered statistically significant. These were performed using GraphPad InStat version 3.05 (GraphPad Software, San Diego California, USA).

\section{RESULTS AND DISCUSSION}

The average number of roots calculated for each explant showed that root production was significantly better in the presence of $0.5 \mathrm{mg} \backslash \mathrm{l}$ NAA than for any of the other treatments (Tab.
1.). Higher concentrations of growth regulators greatly reduced the number of roots generated by each explant while their complete absence had a less marked but still significant effect. Root length was smaller when root number was highest 0.5 mg $\backslash l$ NAA) but it increased in medium with no growth regulators.

The number of shoots for each explant reached the maximal value when $5 \mathrm{mg} \backslash \mathrm{l}$ BA was added to the culture medium and decreased if both an auxin (NAA) and a cytokinin were present (BA). This result is in line with the known effect of auxins and cytokynins as root and shoot inductors, respectively.

With regard to shoot multiplication the results of our experiment are similar with those of Northcutt and Davies (2012) who generated the largest number of shoots using $3 \mathrm{mg} / \mathrm{l} \mathrm{BA}$.

When root growth is analysed it becomes apparent that although the number of roots was highest in medium supplemented with $0.5 \mathrm{mg} \backslash \mathrm{l}$ NAA which runs parallel to the study of Northcutt and Davies (2012), these roots were longer in the control, which is an interesting and surprising development. 


\section{CONCLUSION}

In $S$. purpurea we observed that adding a low concentration of NAA $(0.5 \mathrm{mg} \backslash \mathrm{l})$ to the $1 / 3 \mathrm{MS}$ culture medium resulted in the growth of roots while the absence of plant growth regulators increased root length. The best conditions for shoot multiplication were provided by the addition of $5 \mathrm{mg} \backslash \mathrm{l}$ BA to $1 / 3 \mathrm{MS}$.

\section{REFERENCES}

1. Arndt, W., Mitnik, C., Denzler, K.L., White, S., Waters, R. Jacobs, B.L., Rochon, Y., Olson, V.A., Damon, I.K., Langland, J.O. (2012). In vitro characterization of a nineteenthcentury therapy for smallpox. PLoS One 7(3):e32610.

2. Eid, H.M., Haddad, P.S. (2014). Mechanisms of action of indigenous antidiabetic plants from the Boreal forest of Northeastern Canada. Advances in Endocrinology, article ID 272968, 11 pages.

3. Guerrero-Analco, J., Muhammad, A., Saleem, A., Martineau, L.C., Musallam, L., Eid, H.M., Shang, N., Black, P., Currier, A., Haddad, P.S., Arnason, J.T. (2014). Bioactive phytochemicals from Canadian Boreal forest species used traditionally by Eastern James Bay Cree aboriginals to treat diabetes mellitus. In Jetter, R. (Eds) Phytochemicals Biosynthesis, Function and Application. Recent Advances in Phytochemistry, vol 44. Springer-Verlag Berlin.
4. Harris, C.S., Asim, M., Saleem, A., Haddad, P.S., Arnason, J.T., Bennett, S.A. (2012). Characterizing the cytoprotective activity of Sarracenia purpurea L., a medicinal plant that inhibits glucotoxicity in PC12 cells. BMC Complementary and Alternative Medicine 12:245.

5. Li, S., Pasquin, S., Eid, H.M., Gauchat, J-F., Saleem, A., Haddad, P.S. (2018). Anti-apoptotic potential of several antidiabetic medicinal plants of the eastern James Bay Cree pharmacopeia in cultured kidney cells. BMC Complementary and Alternative Medicine 18:37.

6. Murashige, T., Skoog, F. (1962). A revised medium for rapid growth and bioassays with tobacco tissue cultures. Physiol Plant 15, 474-497.

7. Northcutt, C., Davies, D. (2012). Germination in vitro, micropropagation, and cryogenic storage for three rare pitcher plants: Sarracenia oreophila (Kearney) Wherry (Federally endangered), S. leucophylla Raf., and S. purpurea spp. venosa (Raf.) Wherry. HortScience 47(1), 74-80.

8. Rogers, W.L., Cruse-Sanders, J.M., Determann, R., Malmberg, R.L. (2010). Development and characterization of microsatellite markers in Sarracenia L. (pitcher plant) species. Conserv Genet Resour 2(1), 75-79.

9. Stiefel, C.F. (2000). Meat-eating plants. Science World. http://chanastiefel.com/wp-content/pdfs/meat.pdf Accessed 16.08.2018.

10. Uhnak, K.S. (2003). Micropropagation of carnivorous plants. MS thesis, ETD Collection for University of Rhode Island. Paper AAI3103728. 